\title{
Valentim Gomes Tolentino: a mobilidade econômica e social vivenciada por um pardo no século XIX $\left(\right.$ Zona da Mata Mineira, 1817-1855) ${ }^{1}$
}

\author{
Ana Paula Dutra Bôscaro ${ }^{1 *}$ \\ ${ }^{1}$ Universidade Federal de Juiz de Fora, Juiz de Fora, Minas Gerais, Brasil \\ Elione Silva Guimaräes ${ }^{2 * *}$ \\ ${ }^{2}$ Arquivo Histórico de Juiz de Fora, Juiz de Fora, Minas Gerais, Brasil
}

\section{RESUMO}

O texto discute as possibilidades de mobilidade econômica e social vivenciadas pela populaçấo de pardos livres em Minas Gerais na primeira metade do século XIX, quando a província possuía a segunda maior população de mestiços do Brasil. A questáo foi abordada a partir da trajetória do pardo Valentim Gomes Tolentino, assentado no arraial de Santo Antônio do Paraibuna, futuro município de Juiz de Fora, na Zona da Mata Mineira, nas margens do Caminho Novo. No período em análise, a localidade destacava-se pela produção de alimentos e por uma incipiente economia cafeeira. Exercendo as atividades de tropeiro, lavrador, prestamista, fazendeiro e comerciante, Tolentino alcançou prestígio e riqueza, sendo um dos maiores proprietários de escravos de sua localidade em 1831 e possuidor de mais de uma sesmaria de terras. Ele ostentou a patente de alferes e era senhor de uma fortuna considerável quando faleceu em 1848.

Palavras-chave: mobilidade socioeconômica; tropeiro; livres de cor; Minas Gerais; século XIX.

\section{Valentim Gomes Tolentino: The Economic and Social Mobility Experienced by a Mulatto in the $19^{\text {th }}$ Century (Zona da Mata Mineira, 1817-1855)}

\section{ABSTRACT}

The text discusses the possibilities of economic and social mobility experienced by the population of freed mulattos in Minas Gerais in the first half of the $19^{\text {th }}$ century, when the province had the second largest populations of mixed-race individuals in Brazil. The question was approached through the trajectory of Valentim Gomes Tolentino, a mulatto who settled in the village of

DOI: http://dx.doi.org/10.1590/2237-101X01903906

Artigo recebido em 25 de agosto de 2017 e aprovado para a publicação em 29 de janeiro de 2018.

* Doutoranda da Universidade Federal de Juiz de Fora. E-mail: anapaulaboscaro@gmail.com.

** Pesquisadora do Arquivo Histórico de Juiz de Fora e professora regente da prefeitura de Juiz de Fora.

E-mail: elioneguimaraes@yahoo.com.br.

As datas limites correspondem ao ano do documento mais antigo localizado sobre o personagem em estudo e ao ano em que foi realizado o seu inventário. 
Santo Antônio do Paraibuna, the future municipality of Juiz de Fora, in the region called Zona da Mata Mineira, on the edge of what was then called Caminho Novo (New Way), one of the so-called royal roads that led to Minas Gerais. In the period analyzed, the locality was known for the production of food and by an incipient coffee trade. Working as a drover, farmhand, money lender, farmer and trader, Tolentino conquered prestige and wealth, being one of the largest slaveowners of his village in 1831, possessing more than one many leagues of land. He was a second lieutenant in the Army, and owner of a considerable fortune when he died in 1848.

Keywords: socioeconomic mobility; drover; freed people of color; Minas Gerais; 19th century.

\section{Valentim Gomes Tolentino: la movilidad económica y social vivida por un mulato en el siglo XIX (Zona da Mata Mineira, 1817-1855)}

\section{RESUMEN}

El texto discute las posibilidades de movilidad económica y social vividas por la población de mulatos libertos en Minas Gerais en la primera mitad del siglo XIX, cuando la provincia tenía la segunda más grande población de mestizos de Brasil. La cuestión fue abordada a partir de la trayectoria del mulato Valentim Gomes Tolentino, asentado en la villa de Santo Antônio do Paraibuna, futuro municipio de Juiz de Fora, en la región llamada Zona da Mata Mineira, en las márgenes del Caminho Novo (Camino Nuevo), una de las estradas reales que llevaba a Minas Gerais. En el periodo de análisis, la localidad se destacaba por la producción de alimentos y por una incipiente economía cafetera. Ejecutando las actividades de tropero, labrador, prestamista, hacendado y comerciante, Tolentino alcanzó prestigio y riqueza, siendo uno de los más grandes propietarios de esclavos de su localidad en 1831, y poseedor de más de una concesión de tierras. Él ostentó el rango militar de alférez, y poseía una fortuna considerable cuando falleció en 1848.

Palabras clave: movilidad socioeconómica; tropero; libertos de color; Minas Gerais; siglo XIX.

\section{Valentim Gomes Tolentino: o espaço, o contexto e o homem}

Valentim Gomes Tolentino foi um "homem do Caminho Novo" — tropeiro, comerciante, prestamista, senhor de homens e terras, alferes e fazendeiro. Embora não se saiba sua origem, ele viveu e atuou em Santo Antônio do Paraibuna (atual Juiz de Fora), na Zona da Mata Mineira, pelo menos entre 1831 e 1848 (ano de sua morte). Contudo, antes de conhecermos a sua trajetória, torna-se pertinente apresentar algumas breves consideraçóes sobre a demografia e a economia de Minas Gerais, particularmente do distrito de Santo An- 
Valentim Gomes Tolentino: A MOBILIDAde ECONÔMICA E SOCial ViVenciada por um Pardo no século XIX (Zona Da Mata Mineira, I 8 I7-I 855 )

Ana Paula Dutra Bôscaro e Elione Silva Guimarães

tônio do Juiz de Fora, para melhor dimensionarmos as possibilidades e as circunstâncias em que se deu a mobilidade socioeconômica do personagem em análise. Segundo Saraiva, na década de 1830, a população mineira compunha-se de 626.646 pessoas, das quais 418.422 (66,77\%) eram livres e 208.224 (33,23\%) eram cativos. A população livre da província computava 182.502 "brancos", 190.132 "pardos" e 45.788 "pretos" livres. ${ }^{2}$

Quanto à posse de escravos, consideramos que o número de cativos é um dos elementos utilizados para se definir a riqueza local. Em Minas Gerais, estima-se que os indivíduos brancos compunham o grupo dos mais ricos $(70 \%)$, seguidos pelos pardos (27\%), e pelos negros (3\%). Os proprietários brancos tinham em média oito mancípios, enquanto os pardos tinham quatro, e os pretos, três. Obviamente, como em toda sociedade escravista, os limites eram fluidos e, justamente por isso, encontramos indivíduos brancos despossuídos e pessoas pardas e negras detentoras de fortunas. ${ }^{3}$ A porcentagem de pequenos possuidores de homens era de aproximadamente $80 \%$; eles detinham no máximo 10 cativos. Em Minas Gerais, somente três senhores possuíam mais de 300 pessoas escravizadas. ${ }^{4}$

Saraiva pondera que, na década de 1830, a população da Zona da Mata Mineira era composta por 45.000 indivíduos e detinha a maior concentração de posse de cativos, 44,24\%, se comparada às demais regióes mineiras. ${ }^{5}$ De acordo com o Censo de 1831, o distrito de Santo Antônio do Juiz de Fora computava 1.422 indivíduos, compostos por 589 pessoas livres (considerando os brancos, os pardos livres e os qualificados como forros) e 833 cativos. Em 56,78\% dos lares havia pelo menos um mancípio, mas a maioria dos escravizados estava sob a posse de indivíduos brancos. Naquele Censo, Valentim Gomes Tolentino constava como senhor de 31 cativos, o que correspondia a $28,18 \%$ dos mancípios que se encontravam presentes nos lares chefiados por pessoas pardas. ${ }^{6}$

Na primeira metade do século XIX, o distrito de Santo Antônio do Juiz de Fora pertencia ao termo da Vila de Barbacena. O arraial havia surgido à margem do Caminho Novo e se desen-

\footnotetext{
${ }^{1}$ SARAIVA, Luiz Fernando. O império das minas: café e poder na Zona da Mata Mineira, 1853-1893. Tese (Doutorado) — Universidade Federal Fluminense, Niterói, 2008, p. 89-90.

${ }^{3}$ A possibilidade de um negro ascender à condição de barão não foi inviável no Brasil Imperial, a exemplo de Francisco Paulo Almeida, barão de Guaraciaba. Ver: FERREIRA, Carlos Alberto Dias. Francisco Paulo de Almeida — barão de Guaraciaba: reflexóes biográficas e contexto histórico. Dissertação (Mestrado) — Universo, Vassouras, 2009. Disponível em: <http://livros01.livrosgratis.com.br/cp125855.pdf>. Acesso em: 5 jun. 2017.

${ }^{4}$ Não nos propomos a uma análise própria das fontes, apenas apresentamos ao leitor um panorama da demografia de Minas Gerais e da Zona da Mata, com base na produção historiográfica. Ver: LUNA, Francisco Vidal; KLEIN, Herbert S. Economia e Sociedade Escravista: Minas Gerais e São Paulo em 1830. In: LUNA, Francisco Vidal; COSTA, Iraci del Nero da; KLEIN, Herbert S. (Orgs.) Escravismo em Sáo Paulo e Minas Gerais. São Paulo: Edusp/Imprensa Oficial do Estado de São Paulo, 2009, p. 197-228; GUIMARÁES, Elione. A população não branca e a perspectiva de acesso e manutenção da terra. In: GOMES, Flávio; DOMINGUES, Petrônio (Orgs). Política das raças: experiências e legados da Abolição e da pós-emancipação no Brasil. São Paulo: Selo Negro Ediçôes, 2014, p. 211-230.

5 SARAIVA, Luiz Fernando. O império das minas: café e poder na Zona da Mata Mineira, 1853-1893, op. cit., 2008, p. 91.

${ }^{6}$ Arquivo Público Mineiro (APM). Coleção Mapas de População (MP), CX.07-DOC.05. Disponível em: <http://www.siaapm.cultura.mg.gov.br/modules/mapas_populacao/brtacervo.php?cid=481>.
} 
volveu ao redor de vendas e pousos que abrigavam e forneciam alimentos aos tropeiros e viajantes que circulavam pela estrada, suprindo também seus animais. Desde a abertura do Caminho Novo, no final do século XVII e início do século XVIII, a coroa adotou uma política de distribuição de terras ao longo da estrada, concedendo sesmarias e legalizando apossamentos. ${ }^{7}$

Situado no Vale Paraíba mineiro, o distrito de Santo Antônio do Juiz de Fora, na primeira metade do oitocentos, tinha uma economia predominantemente voltada para a produção de alimentos, já se vislumbrando o desenvolvimento de uma cultura cafeeira. Entre 1830 e 1850, a localidade, impulsionada pela produção da rubiácea, vivenciaria um grande desenvolvimento econômico, acompanhado de uma explosão demográfica, visto que a cafeicultura nascente necessitava da contínua incorporação de braços e terras. Em 1850, Santo Antônio do Juiz de Fora se emancipou de Barbacena e, nos anos seguintes, assumiu a posição de maior produtor de café da região.

$\mathrm{O}$ primeiro contato que tivemos com Valentim Gomes Tolentino ocorreu por meio dos registros de "despachos de escravos e de passaportes" lançados pela Intendência de Polícia da corte entre 1809 e 1833. Entre 1817 e 1831, há 21 registros de passagens ou despachos que foram realizados pelo indivíduo em questão. No primeiro registro, de 19 de maio de 1817, ele foi descrito como natural e morador de Minas Gerais, então com 30 anos de idade, um homem pardo, alto, com rosto comprido e pouca barba. ${ }^{8}$ Como esses registros estão relacionados a uma das principais atividades desempenhadas pelo personagem em estudo, voltaremos a ele mais adiante.

No ano 1831, Valentim Gomes Tolentino apareceu na Lista Nominativa de Habitantes recenseado como um homem pardo, entáo com 42 anos, casado com a parda Joaquina Antônia, de 33 anos, e, aparentemente, com a presença de cinco filhos que com o casal residiam naquele momento: João Gomes, Antônio Gomes, José, Margarida e Manoela; os dois primeiros com 20 anos e os demais com oito, nove e três anos, respectivamente. Consta ainda no censo, mas em fogo próprio, vivendo com o marido, a filha Ana Rita. Tolentino foi qualificado com o ofício de lavrador e de tropeiro, ocupação que era desempenhada também por João e Antônio Gomes, visto que os possíveis filhos mais velhos foram assim descritos pelo recenseador." No "fogo" de Valentim, vivia também Narciso

\footnotetext{
${ }^{7}$ POLLIG, Joáo Victor Diniz Coutinho. Apropriação de terras no Caminho Novo. Dissertação (Mestrado em História) - Universidade Federal do Rio de Janeiro, Rio de Janeiro, 2012.

${ }^{8}$ Arquivo Nacional do Rio de Janeiro (AN-RJ). Intendência de Polícia da Corte. Descrição no Códice 421, v. 8 , fls. $210,19 / 5 / 1817$.

9 Para as várias interpretaçóes do termo "tropeiro", ver: GOULART, José Alípio. Tropas e tropeiros na formação do Brasil. Rio de Janeiro: Conquista, 1961; LENHARO, Alcir. As tropas da moderação: o abastecimento da corte na formação política do Brasil: 1808-1842. São Paulo: Edições Símbolo, 1979; FRASSON, Antônio Carlos; GOMES, Silvestre Alves. Tropeirismo: processo civilizatório da região sul do Brasil, 2010; GUIMARÃES, Elione. Tropas e tropeiros na Minas Gerais Oitocentista: Francisco Garcia de Mattos, um tropeiro na Zona da Mata Mineira. In: Anais do VI Congresso Brasileiro de História Econômica e 7t Conferência Internacional de Empresas, Conservatória, 2005.
} 
Valentim Gomes Tolentino: A MOBILIDAde ECONÔMICA E SOCial ViVenciada por um Pardo no século XIX (Zona Da Mata Mineira, I 8 I7-I 855 )

Ana Paula Dutra Bôscaro e Elione Silva Guimarães

Mendes Linhares, um homem pardo de 24 anos, que era seu genro, casado com Ana Rita, e que exercia a atividade de feitor.

A análise do testamento e dos inventários de Valentim Gomes Tolentino e de sua mulher Joaquina Antônia do Nascimento nos possibilitou traçar uma pequena biografia do casal, que embora fragmentada, nos permite conhecer alguns aspectos da trajetória desta família. Valentim nasceu na década de oitenta do século XVIII, em lugar ignorado, e faleceu em Juiz de Fora no dia seis de agosto de 1848. Desconhecemos o nome de seu pai; sua mãe chamava-se Clara Maria Tolentino. A esposa, Joaquina Antônia do Nascimento, nasceu e foi batizada na Rocinha de Pedro Alves (atual município de Santos Dumont), por volta do ano 1798, e faleceu em Juiz de Fora no dia 19 de agosto de 1857. Em seu testamento, Joaquina declarou ter tido nove filhos, mas só nomeou os quatro que ainda estavam vivos quando testou: Ana Rita, Maria Magdalena, Margarida Escossia e Manoela. ${ }^{10}$

No que se refere ao filho José, constante na lista de 1831, faleceu vítima do cólera morbus, por volta de 1854 ou $1855 .{ }^{11}$ Avaliamos que os outros dois indivíduos livres que aparecem no "fogo" do casal Valentim e Joaquina Antônia, João Gomes e Antônio Gomes, de fato eram filhos de Valentim, mas somente dele. Em 1831, ambos tinham a mesma idade, 20 anos, sendo-nos possível deduzir que eram gêmeos. Aparentemente João faleceu em estado de solteiro antes do pai, pois não temos mais informaçóes sobre ele. Antônio apareceu em um processo de dano datado de 1861, no qual foi qualificado como filho de Valentim Gomes Tolentino e descrito como natural de Barbacena. ${ }^{12}$ Antônio foi também citado no testamento de Valentim, que para ele legou parte dos seus bens, como se verifica na verba a seguir: "Da minha Terça dar-se-á uma quantia igual a que tiverem os filhos legítimos na sua herança paterna, e os remanescentes dela, depois de cumpridos os meus legados, se dividirão pelos meus herdeiros legítimos." 13

Apresentada a família de Tolentino, voltemos ao Censo de 1831 para avaliar as principais características dos cativos possuídos por este sujeito. No ano em questão, ele era proprietário de 31 mancípios, sendo 24 homens e apenas sete mulheres. Dos homens, somente dois eram crioulos, um era mestiço cabra e os demais eram africanos, a grande maioria em idade

\footnotetext{
${ }^{10}$ As informaçóes biográficas foram obtidas da Lista Nominativa de 1831 (Listas Nominativas de Habitantes para o ano de 1831. Cx. 07, doc. 05. Disponível em: <http://www.siaapm.cultura.mg.gov.br/modules/ mapas_populacao/brtacervo.php?cid=481>. Acesso em: 22 mai. de 2017), e também em: Arquivo Histórico da Universidade Federal de Juiz de Fora (doravante AHUFJF). Inventário de Valentim Gomes Tolentino, cx. 97B, 1849. AHUFJF. Inventário de Valentim Gomes Tolentino, cx. 9B, 1855. AHUFJF, Ação de Força Velha de Valentim Gomes Tolentino, controle: 30A08, 1838. AHUFJF. Inventário de Joaquina Antônia do Nascimento, cx. 50B, 1857. Maria Magdalena não consta do "fogo" paterno, pois aparece na Lista Nominativa de João Gomes, em companhia do marido.

${ }^{11}$ Uma matéria publicada no jornal O Pharol, em 1889, relativa a epidemias, informa que, em 1854 ou 1855 , José Gomes Tolentino foi a primeira vítima do cólera morbus em Juiz de Fora. Biblioteca Nacional, jornal $O$ Pharol. 0000023-2Alt=002552Lar=001672LargOri=003570AltOri=005448. Acesso em: 20 jul. 2017.

${ }^{12}$ Arquivo Histórico de Juiz de Fora (AHJF). Fundo Benjamin Colucci, Processos Criminais do Período Imperial. Processo de Dano, 28/8/1861.

${ }^{13}$ AHUFJF. Inventário de Valentim Gomes Tolentino, cx. 97B, 1849.
} 
produtiva, o que significa dizer que tinham idades variáveis entre 14 e 44 anos. ${ }^{14}$ As sete mulheres cativas foram descritas como africanas e também estavam em plena idade produtiva. Destes 31 mancípios, quatro eram casados; havia uma criança e um idoso.

O perfil da escravaria indica que a reposição da mão de obra cativa se dava, majoritariamente, via tráfico, o que se verifica pelo desequilíbrio sexual a favor dos cativos do sexo masculino, sendo a proporção de mulheres inferior ao número de homens. De acordo com Manolo Florentino, o maior percentual de homens africanos em idade produtiva podia ser o indicativo de que o tráfico foi uma das vertentes utilizadas para a reposição da mão de obra mancípia, pois o comércio transatlântico de almas privilegiava, sobretudo, a importação de homens africanos jovens e adultos. ${ }^{15}$

Cuidar de um domicílio, roças de alimentos e, principalmente, de lavouras de café era um trabalho árduo e extenso. Justamente por isso, o auxílio de uma companheira, de filhos, genros e cativos saudáveis com boa disposição física contribuíam para o sucesso das tarefas executadas. No caso específico do personagem em análise, a atividade de tropeiro o mantinha em constantes viagens; era, portanto, ausente de sua propriedade e de suas lavouras. Em suas terras, as atividades de lavrar e de colher ficavam a cargo dos escravizados, gerenciadas pelo genro feitor.

A atividade tropeira, que foi exercida por Valentim Gomes Tolentino, intensificou-se de maneira organizada e como uma espécie de "profissão" a partir da descoberta do ouro em Minas Gerais, no final do século XVII, momento no qual o transporte das riquezas naturais da colônia tornou-se extremamente necessário para manutenção da metrópole portuguesa. As minas recém-descobertas caracterizavam-se não apenas pela abundância de ouro, mas também pela carência de produtos necessários à subsistência de seus exploradores, pela desordem e pelas constantes crises de fome. ${ }^{16}$ Essa situação contribuiu para a intensificação das atividades do tropeiro, e muitos foram os homens que se dedicaram a transitar pelas estradas recém-construídas. As viagens eram realizadas com a ajuda de um familiar, normalmente o filho mais velho, responsável por comandar a força de trabalho dos cativos. Os mancípios

\footnotetext{
${ }^{14}$ Iraci Costa estima a idade ativa entre 15 e 64 anos. Cf.: COSTA, Iraci del Nero da. Arraia miúda: um estudo sobre os náo proprietários de escravos no Brasil. São Paulo: MGSP editores, 1992, p. 25. Carlos Bacellar desloca essa faixa para entre 8 e 50 anos. Cf.: BACELLAR, Carlos de Almeida Prado. Viver e sobreviver em uma vila colonial: Sorocaba séculos XVIII e XIX. São Paulo: Fapesp/Annablume, 2001, p. 148. Bergad fala em melhor idade útil para os cativos entre 15 e 40 anos. Cf.: BERGAD, Laird. Escravidão e história econômica: demografia de Minas Gerais, 1720-1888. Bauru: Edusc, 2004, p. 222.

${ }^{15}$ Ver: FLORENTINO, Manolo. Em costas negras: uma história do tráfico de escravos entre África e o Rio de Janeiro. São Paulo: Companhia das Letras, 2002, p. 50-60; SCHWARTZ, Stuart. Escravos, roceiros e rebeldes. Bauru: Edusc, 2001, p. 286-290.

${ }^{16}$ O final do século XVII e o início do século XVIII representam um período bastante conturbado da história de Minas Gerais. Para a melhor compreensão dos fatos, ver: ANASTASIA, Carla. Salteadores, bandoleiros e desbravadores nas matas gerais da Mantiqueira (1783-1786). In: PRIORE, Mary del (Org.). Revisão do paraiso. Rio de Janeiro: Campus, 2002; ANASTASIA, Carla; LEMOS, Carmen. Vila Rica: ocupação improvisada. Oficina da Inconfidência, Ouro Preto, v. 1, n. 0, p. 26-41, dez. 1999.
} 
Valentim Gomes Tolentino: A MOBILIDAde ECONÔMiCa E SOCIAL VIVENCIAdA POR um PaRdo No sÉCulo XIX (Zona Da Mata Mineira, I 8 I7-I 855 )

Ana Paula Dutra Bôscaro e Elione Silva Guimarães

eram encarregados dos serviços pesados e, na maior parte das vezes, ficavam responsáveis por descarregar as mercadorias, cozinhar e proteger a carga. ${ }^{17}$

Desse modo, a presença de escravizados homens e com boa disposição física foi essencial para o funcionamento das atividades. Em relação à composição das tropas, Hermann Burmeister destacou que:

O tropeiro, montado a cavalo, superintende o conjunto. O seu cavalo é que indica o caminho à tropa; as mulas seguem-no (...). Os trabalhos de carregar e descarregar ocupam sempre dois escravos, que suspendem o fardo ao mesmo tempo de ambos os lados do animal, pois este não suporta o peso de um só lado (...). Por isto é necessário levar no mínimo dois escravos, mesmo que a tropa não tenha mais de quatro ou cinco animais, desde que não se queira ajudar em pessoa este trabalho (...). ${ }^{18}$

O movimento das tropas formou novos núcleos de povoamento e contribuiu para o desenvolvimento de localidades já existentes. ${ }^{19}$ Essa movimentação que levava e trazia diversas mercadorias influenciou não apenas a integração e a ocupação do território, mas também o surgimento da figura do tropeiro e o dinamismo da economia. Os tropeiros faziam circular as mercadorias e, por extensão, realizavam a função de levar notícias e informações, constituindo-se como um elemento vital para a manutenção do ciclo econômico vigente.

Em Minas Gerais, o tropeirismo conheceu seu auge quando a cultura cafeeira começou a florescer, pois, com a precariedade das estradas e a ausência de ferrovias para escoar a crescente produção, os tropeiros eram os grandes responsáveis por recolher e transportar o café. ${ }^{20}$ Ademais, cabe-nos ressaltar que o modo de organização desses trabalhadores possibilitou a manutenção dos fluxos comerciais e, consequentemente, o controle dos transportes, do comércio e do preço final dos produtos. $^{21}$ Tal atividade certamente contribuiu para a formação da riqueza de Valentim, propiciando uma maior inserção social nas diversas localidades por onde transitou.

\footnotetext{
${ }^{17}$ Ver: FRANCO, Maria Sylvia de Carvalho. Homens livres na ordem escravocrata. 4. ed. São Paulo: Fundação Editora da Unesp, 1997, p. 71; CORDEIRO, Filipe. Os tropeiros no século XXI e o sentido contemporâneo dessa atividade: estudo de caso no Vale do Paraíba e Serra da Mantiqueira. In: X Encontro Regional Sudeste de História Oral, Campinas. Encontro Regional Sudeste de História Oral - Educação das sensibilidades: Violência, desafios contemporâneos. Campinas: Centro de Memória da Unicamp, 2013.

${ }^{18}$ BURMEISTER, Hermann. Viagem ao Brasil através das provincias do Rio de Janeiro e Minas Gerais: visando especialmente a história natural dos distritos auri-diamantíferos. São Paulo: Martins, 1952, p. 72.

${ }^{19}$ FRANCO, Maria Sylvia de Carvalho. Homens livres na ordem escravocrata, op. cit., p. 71.

${ }^{20}$ Cf.: GOULART, José Alípio. Tropas e tropeiros na formação do Brasil, op. cit.; LENHARO, Alcir. As tropas da Moderação: o abastecimento da corte na formação política do Brasil: 1808-1842, op. cit.; FRASSON, Antonio Carlos; GOMES, Silvestre Alves. Tropeirismo: processo civilizatório da região sul do Brasil, op. cit.; GUIMARÃES, Elione Silva. Tropas e tropeiros na Minas Gerais Oitocentista: Francisco Garcia de Mattos, um tropeiro na Zona da Mata Mineira, op. cit.

${ }^{21}$ Para mais informações, ver: CORDEIRO, Filipe. Os tropeiros no século XXI e o sentido contemporâneo dessa atividade: estudo de caso no Vale do Paraíba e Serra da Mantiqueira, op. cit.; GOULART, José Alípio. Tropas e tropeiros na formação do Brasil, op. cit.
} 
VAlentim Gomes Tolentino: A MOBILIDAde ECONÔMICA E SOCIAL VIVENCIADA por um pardo no século XIX (Zona da Mata Mineira, i 8 I 7 -I 855 )

Ana Paula Dutra Bôscaro e Elione Silva Guimarães

Os "despachos de escravos e de passaportes" 22 nos permitem ratificar, por meio dos registros que se referem a Valentim Gomes Tolentino, a importância que a atividade de tropeiro assumiu para a movimentação e o desenvolvimento da economia nas Gerais, contribuindo também com seu enriquecimento pessoal. Em 1818, com então estimados 30 anos, Valentim realizou duas viagens ao Rio de Janeiro, muito provavelmente com o intuito de comercializar e abastecer a corte, levando produtos destinados à exportação e gêneros alimentícios. Nos dias 17 de abril e 30 de junho, ele retornou para Minas Gerais, na companhia de alguns de seus cativos e de seus camaradas. ${ }^{23}$

Ainda que a fonte não descreva o motivo das viagens e os produtos comercializados, a presença de camaradas e de alguns mancípios que já lhe pertenciam permite-nos inferir que os trajetos percorridos por Valentim estavam diretamente relacionados ao ofício de tropeiro que por ele era desempenhado. Tanto o é que, em 1822, realizou mais duas viagens ao Rio de Janeiro e, ao retornar para Minas Gerais, novamente encontrava-se na companhia de três de seus cativos e mais seis camaradas. ${ }^{24}$

Como visto, em 1831, o tropeiro Valentim Gomes Tolentino muito se destacava perante os demais homens livres de cor da localidade onde estava assentado, possuindo um número de escravizados demasiadamente superior ao de outros tantos indivíduos brancos que ali residiam. Decerto, a escravaria que pertencia ao pardo Valentim foi sendo formada ao longo dos anos, o que pode ser comprovado por meio dos registros de despachos por ele efetuados. Em 1828, por exemplo, ele despachou para Minas Gerais dez mancípios “novos”, provavelmente, cativos recém-chegados da África. Em 1829, ele executou outro despacho de 13 escravos “novos". Remessas menores também foram realizadas, como a de 1828 e a de 1830, quando ele despachou quatro e dois escravizados "novos" para Minas Gerais. ${ }^{25}$ É provável que ele comercializasse esses cativos, mas acreditamos que alguns eram incorporados à sua própria escravaria.

\footnotetext{
${ }^{22}$ A documentação alusiva à Intendência Geral de Polícia da Corte, que está sob a guarda do Arquivo Nacional, teve suas informaçóes sistematicamente levantadas, culminando na elaboração de um extenso banco de dados informatizado, que foi proposto pelo Instituto de Pesquisa Econômica Aplicada (Ipea) e confeccionado pelo Laboratório de Pesquisa em História Social (LIPIHS) da UFRJ. Os despachos e os passaportes de escravos englobam os códices 390, 421, 424 e 425, abarcam o período de 1809 a 1833 e formam um conjunto de 43 volumes. Em suma, esses documentos tratam do comércio interno que foi praticado no Centro-Sul do país em finais do século XVIII e na primeira metade do século XIX, sobretudo no que tange à comercializaçáo de cativos. ${ }^{23}$ AN-RJ. Intendência de Polícia da Corte. Descrição no Códice 421, v. 10, fls. 87 e 260, 17/4/1818 e 30/6/1818.

${ }^{24}$ AN-RJ. Intendência de Polícia da Corte. Descrição no Códice 421, v. 16, fls. 283, 27/6/1822. Descrição no Códice 421, v. 17, fls. 5, 2/3/1822.

${ }^{25}$ Nessa documentação, os escravos aparecem designados ora como "novos", ainda sem nome cristão, ora como "ladinos", já com nome cristão, isto é, batizados na África ou no Brasil. Não obstante, ainda que os escravos "novos" forneçam uma maior margem de segurança na análise do número de escravizados vindos do Atlântico, os registros da polícia não atestam se esses cativos eram recém-chegados à América portuguesa ou se aqui já estavam estabelecidos desde longa data. AN-RJ. Intendência de Polícia da Corte. Descrição no Códice 421, v. 21, fls. 903, 15/3/1828. Descriçâao no Códice 421, v. 21, fls. 2211, 29/1/1829. Descrição no Códice 421, v. 21, fls. 1489, 13/8/1828. Descrição no Códice 421, v. 23, fls. 283, 1/7/1830.
} 
Ainda que a posse de mancípios pudesse conferir prestígio, ajudar na manutenção da propriedade e também nas tarefas que eram desempenhadas pelo senhor, lidar e manter em "ordem" um elevado número de cativos podia acarretar uma série de complicaçóes. A título de exemplo, citamos o caso do escravo Manuel, que no ano de 1834 foi réu de um Processo Crime aberto para avaliar o "uso de armas proibidas". Manuel era um mancípio cabra de 54 anos que já estava sob a posse de Valentim em $1831 .^{26}$

Em que pese os problemas enfrentados, Valentim Gomes Tolentino tanto se destacou em meio ao grupo social no qual estava inserido que, em 1836, apareceu ostentando a patente de alferes, ${ }^{27}$ possivelmente da Guarda Nacional, demonstrando-nos que o seu reconhecimento não se processou apenas perante os seus iguais, mas também diante do governo provincial. Uma das estratégias utilizadas por homens livres de cor foi o ingresso nas forças militares, visto que essas colocações poderiam vir a proporcionar prestígio e poder, além de trazer certas isenções de impostos e outros privilégios. Desse modo, ocupar um posto nas ordenanças não se traduzia necessariamente em ganhos monetários, mas, sim, em prestígio, honra e posiçáo de comando. ${ }^{28}$ Certamente o desejo de possuir patentes provinha mais do acesso aos títulos do que da execução dos deveres propriamente ditos, pois estabelecia uma hierarquia capaz de conferir distinção na localidade em que vivia.

Além da patente de alferes, a mobilidade social alcançada por Valentim Gomes Tolentino pôde ser constatada apenas em alguns documentos esporádicos, impossibilitando-nos aprofundar os debates sobre essa questão. Todavia, os documentos coligidos até o momento apontam nessa direção, seja por meio de sua patente, escravaria, monte mor acumulado, ou mesmo das relaçóes pessoais que construiu com os principais potentados do distrito de Santo Antônio do Juiz de Fora. Além disso, o levantamento inicial dos bens que pertenceram aos seus filhos demonstra-nos que estes também conseguiram usufruir do legado material e imaterial deixado pelo pai. ${ }^{29}$

Em 1831, por exemplo, assinou uma subscrição em apoio ao Governo Regencial, juntamente com outros proprietários da freguesia de Simão Pereira (à qual estava vinculado o

\footnotetext{
${ }^{26}$ Arquivo Histórico Municipal Professor Altair José Savassi (doravante AHMPAS). Processo Crime, cx. 78, ordem $15,1834$.

${ }^{27}$ AN-RJ. Ação de Força Nova. Antonio João do Valle Amado e Valentim Gomes Tolentino, 1836. Código de Referência 84.0. ACI.03632.

${ }^{28}$ Cf.: COTTA, Francis Albert. Os terços de homens pardos e pretos libertos: mobilidade social via postos militares nas Minas Gerais no século XVIII. Mneme, Rio Grande do Norte, v. 3, n. 6, p. 1-19, 2002. SALDANHA, Henrique Flávio Dias. O império da ordem: Guarda Nacional, coronéis e burocratas em Minas Gerais na segunda metade do século XIX, 1850-1873. Tese (Doutorado em História) — Universidade Estadual Paulista Júlio de Mesquita Filho, São Paulo, 2009.

${ }^{29}$ De acordo com as análises de Roberto Guedes, a ascensão social se dá por meio de um movimento geracional, que ocorre dentro do âmbito familiar. Cf.: GUEDES, Roberto. Ofícios mecânicos e mobilidade social: Rio de Janeiro e São Paulo (Sécs. XVII-XIX). Topoi, Rio de Janeiro, v. 7, n. 13, p. 379-423, 2006. Sobre herança imaterial, ver: LEVI, Giovanni. A herança imaterial: trajetória de um exorcista no Piemonte do século XVII. Rio de Janeiro: Civilização Brasileira, 2000. Dado o limite de espaço de que dispomos, torna-se impossível abordar neste artigo a trajetória dos filhos de Valentim Gomes Tolentino.
} 
distrito de Santo Antônio do Juiz de Fora). Demonstrando preocupação com as revoltas que assolavam diversos pontos do país e da província, os paroquianos se posicionaram frente à Câmara de Barbacena, sob a alegaçáo de que estavam empenhando esforços para a consolidação do governo vigente e para a criação das Guardas Municipais. ${ }^{30}$

Pouco mais tarde, em 1836, vamos encontrá-lo empenhado em auxiliar na melhoria das estradas entre Minas Gerais e a corte. Segundo Blasenheim, os transportes se desenvolveram lentamente na Mata Mineira, e nem mesmo o crescimento das lavouras cafeeiras propiciaram, de imediato, uma melhoria das estradas. Ao governo provincial faltavam meios de financiar grandes projetos e não houve iniciativa privada antes de 1836, quando José Antônio da Silva Pinto ganhou um contrato para ampliar o Caminho Novo, obra que se realizou sob a orientação do engenheiro alemão Henrique Guilherme Fernando Halfeld. ${ }^{31}$ Em uma das visitas do engenheiro à regiáo, com a finalidade de realizar estudos e elaborar as propostas das obras que seriam realizadas, novamente encontramos Valentim Gomes Tolentino que, juntamente com Albino Cerqueira Leite, acompanhou o engenheiro "em seus exames", como consta no trecho abaixo:

Dos ofícios do Engenheiro Fernando Halfeld (...) consta, que (...) Cumprindo-lhe verificar a medição da Estrada para reconhecer a vantagem dos atalhos, partiu o dito Engenheiro da ponte do Rio Paraibuna e havendo-se-lhe reunido na Rocinha de Simáo Pereira os Cidadãos Albino de Cerqueira Leite, e Valentim Gomes Tolentino que o acompanharão em seus exames, conheceu desde logo que a picada náo oferecia terreno próprio para uma Estrada cômoda, e em direção reta, por conter frequentes elevaçôes e depressốes, seguindo o rumo N.E, e o E., e que apenas se poderia aproveitar parte dela... ${ }^{32}$

Embora o Caminho Novo tenha facilitado bastante o trânsito entre as províncias do Rio de Janeiro e de Minas Gerais, ele era bastante acidentado e perigoso, tal como demonstram os relatos dos muitos viajantes que por ele transitavam. O trecho entre a capital do império e Santo Antônio do Juiz de Fora era íngreme, recortado por montanhas, estreito e alagado, complicando-se principalmente no período das águas, quando o volume dos rios se somava aos brejos. ${ }^{33}$

Por um lado, a presença de Valentim Gomes Tolentino, juntamente com Albino Cerqueira Leite, ${ }^{34}$ membro de uma das famílias mais ricas de Simão Pereira, acompanhando o levanta-

\footnotetext{
${ }^{30}$ BN, Hemeroteca Digital: jornal O Universal, 24 de agosto de 1831. I0004087-2Alt=002128Lar=001349L $\operatorname{argOri}=002048$ AltOri $=003231$. Acesso em: 6 abr. 2017.

${ }^{31}$ BLASENHEIM, Peter L. As ferrovias de Minas Gerais no século XIX. Lócus: Revista de História. Juiz de Fora: Núcleo de História Regional — UFJF, EDUFJF, v. 2, n. 2, p. 81-110, 1996.

${ }^{32}$ BN, Hemeroteca Digital: jornal O Universal, 15 de março de 1837. I0007575-9Alt=002336Lar=001536La rgOri=002048AltOri=003115. Acesso em: 6 abr. 2017.

${ }^{33}$ ESCHWEGE, Wilhelm Ludwig von. Jornal do Brasil, 1811-1817 ou Relatos diversos do Brasil, coletados durante expediçôes cientificas por Wilhelm Ludwig von Eschwege. Belo Horizonte: Fundação João Pinheiro, Centro de Estudo Históricos e Culturais, 2002, p. 238. (Coleção Mineriana, Série Clássicos)

${ }^{34}$ Albino Cerqueira Leite era filho de José de Cerqueira Leite, donos da Fazenda Rocinha de Simão Pereira, além de outras quatro sesmarias.
} 
mento do engenheiro Halfeld, pode ser considerado um sinal de prestígio e o indicativo de sua rede de relacionamentos com a elite local. Por outro lado, sua participação nesses estudos tinha sua razão de ser e, para ele, teve significados diversos. Sendo senhor de tropas, ele com certeza conhecia em detalhes os meandros da estrada que se desejava melhorar e, justamente por isso, podia auxiliar o engenheiro indicando as trilhas. A melhoria da estrada, por sua vez, traria a todos os que tinham propriedades próximas ao trajeto, como era o caso de Valentim, condiçóes de ampliar seus ganhos, por meio do fornecimento de alimentos aos tropeiros e seus animais, pousos etc. No caso específico dos tropeiros, estradas melhores significavam também a possibilidade de ampliar seus rendimentos, pois, com a diminuição do tempo de transporte e o menor número de homens e animais por percurso, os lucros com o comércio tendiam a ser maiores.

Todos esses fatores auxiliaram Valentim Gomes Tolentino a ampliar sua rede de relacionamentos e a aumentar a sua fortuna. Pouco antes de sua morte, em 1848, há registro de sua participação nas obras da nova igreja que estava sendo construída no arraial de Santo Antônio do Juiz de Fora. As atividades tinham por provedor José Ribeiro de Resende (futuro barão de Juiz de Fora), José Damaso da Costa, que era tesoureiro, e Valentim Gomes Tolentino e Antônio Dias Tostes como procuradores..$^{35}$ Certamente, os que conhecem a história de Juiz de Fora sabem que esses homens eram membros da elite juizdeforana da época.

Além disso, estima-se que Valentim Gomes Tolentino tinha certa educação, sabia ler e escrever, pois há um crédito passado e assinado por ele que consta junto ao seu inventário. Em 1846 vamos encontrá-lo como assinante do livro, organizado por Manoel Antonio Ferreira da Silva e dedicado a Manoel Ribeiro de Almeida, publicado pela Typographia Universal de Laemmert (Rio de Janeiro). ${ }^{36}$ Por fim, o fato de, em 1847, ser qualificado como votante no distrito de Juiz de Fora, freguesia de Simão Pereira, ${ }^{37}$ atesta sua proeminência frente à sociedade na qual estava inserido.

\section{Riqueza e mobilidade social na vivência do pardo Valentim Gomes Tolentino}

O testamento e os dois inventários post-mortem de Valentim Gomes Tolentino muito nos ajudaram a analisar a mobilidade socioeconômica que foi vivenciada por esse indivíduo. O primeiro inventário foi aberto em 1849 , logo após sua morte, mas a viúva o interrompeu por não ter conseguido resolver o "deve e haver" do marido. Em 1855, tendo

\footnotetext{
${ }^{35}$ ESTEVES, Albino. Álbum do Município de Juiz de Fora. 3. ed. Juiz de Fora: Funalfa Edições, 2008, p. 53. ${ }^{36}$ Sobre Tolentino e os demais assinantes dos "Bosquejos Poéticos ou Coleçáo de Poesias", ver: <https://books. google.com.br/books?id=mOJiAAAAcAAJ\&pg=PA235\&lpg=PA235\&dq=valentim+gomes+tolentino+bosqu ejos+poeticos\&source=bl\&ots=7WwGGr41QR\&sig=t7E4hpnLQOzTPQ89qnbQbj2i11s\&hl=pt-BR\&sa=X \&ved=0ahUKEwjRh66f4fbXAhVFS5AKHRfwDgIQ6AEIKDAA\#v=onepage\&q=valentim\%20gomes\%20 tolentino\%20bosquejos\%20poeticos\&f=false>. Tipografia Universal (na época grafada Typographia Universal) foi uma empresa editorial que compreendia editora e livraria, fundada e pertencente aos irmáos Eduardo e Henrique Laemmert, que esteve em atividade no Rio de Janeiro, no século XIX, e era conhecida como Laemmert. ${ }^{37}$ AHJF. Livros do Cartório de Simão Pereira, livro 19, fls. 12.
} 
falecido uma das filhas do casal, deixando órfãos menores, fez-se necessário abrir-se outro inventário pelo juiz de órfãos.

O testamento do alferes Valentim foi realizado em agosto de 1848, ano de sua morte. Homem católico que era, deixou verbas para satisfazer os ritos religiosos. Estipulou que fossem rezadas cem missas pela sua alma e mais cinquenta pela alma de seus falecidos cativos. Estabeleceu que os legítimos herdeiros deveriam pagar a quantia de 500\$000 mil réis à igreja do Santo Antônio do Juiz de Fora, devido a uma promessa que ele havia feito. Senhor de homens, concedeu liberdade a alguns de seus mancípios, declarando que, após o seu falecimento, a cativa Mariana gozaria de plena liberdade e que os escravizados Pedro e Tereza (casados), bem como o mancípio Felisbindo, ficariam incumbidos de servir a dona Joaquina Antônia do Nascimento até o momento de sua morte, estando posteriormente libertos. ${ }^{38}$

Com a iminência da morte, era preciso acertar também as contas terrenas e, justamente por isso, não era incomum que o testador declarasse suas dívidas ativas e passivas no testamento. Valentim alegou ter contas de "deve e haver" com Manoel Ferreira da Silva, morador de Santa Quitéria, entấo termo de Santa Luzia. ${ }^{39}$ Os termos da declaração dessas dívidas permitiram-nos supor que Valentim veio da regiáo mineradora, ou pelo menos lá viveu por algum tempo, local em que supostamente havia iniciado sua fortuna. Outra possibilidade é a de que tivesse investimentos e negócios em Santa Quitéria, visto que a atividade tropeira lhe proporcionava constante mobilidade.

Reforça a hipótese de que Valentim nasceu ou viveu na regiáo de Sabará a amizade, os negócios e a aliança firmada entre ele e o também pardo Manoel Mendes Linhares. Este último foi casado com Francisca Gomes de Assis e era pai de Narciso e Lucas, genros de Valentim. Em seu testamento, Manoel Mendes Linhares declarou-se natural de Santa Luzia do Sabará, filho natural de Florência e de José Mendes Linhares. Note-se que o sobrenome de sua esposa, Gomes, é o mesmo de Valentim, o que aponta um possível parentesco entre Francisca Gomes de Assis e Valentim Gomes Tolentino. ${ }^{40}$

Mas voltemos ao testamento do tropeiro Valentim Gomes Tolentino:

Declaro que tenho contas de deve e de haver com Manoel Ferreira da Silva, (...) - a saber é uma escritura de nove contos e tanto e sem juros a Tanazio Nogueira da Silva (...) para creditar na referida escritura há dois contos e tanto, que eu lhe devia. (...) mais dois contos e cinquenta mil réis de oito açôes do Morro da Glória (...) mais um conto de réis que por ele entrei na

\footnotetext{
${ }^{38}$ AHUFJF. Inventário de Valentim Gomes Tolentino, cx. 97B, 1849.

39 Santa Luzia foi fundada em 1692. Em 1697, o povoado foi erguido e, em 1856, foi emancipado e desmembrado de Sabará. Tornou-se um importante centro comercial, constituindo-se como o ponto de parada de diversos tropeiros que vinham negociar e comprar mercadorias. Para mais informações: Instituto Brasileiro de Geografia e Estatística (IBGE). Disponível em: <https://cidades.ibge.gov.br/brasil/mg/santaluzia/historico>. Acesso em: 22 mai. 2017.

${ }^{40}$ Narciso e Lucas eram filhos de Manoel Mendes Linhares e de Francisca Gomes de Assis. Ver: AHPJAS, COD. 15vc, cx. 3, ordem 14 - Contas Testamentárias de Manoel Mendes Linhares, 1850.
} 
VAlentim Gomes Tolentino: A MOBILIDAde ECONÔMICA E SOCIAL VIVENCIADA por um pardo no século XIX (Zona da Mata Mineira, i 8 I 7 -I 855 )

Ana Paula Dutra Bôscaro e Elione Silva Guimarães

Sociedade da Lage, cujo conto retirou-se na dissoluçấo da Sociedade em suas despesas. (...) recebi em contas de José Fernandes de Oliveira por ordem de Bernardo Moreira Barbosa dois contos e sessenta mil réis. Assim, mais seiscentos mil réis por ordem do mesmo Barbosa (...) em poder do dito Ferreira existem cobranças minhas de diversos em Santa Quitéria, e juntamente dinheiros dados e recebidos e cujas contas ele apresentara e se levara em conta. (...) passei um crédito de um conto de reis a Bernardo, ou Antônio Moreira Barbosa, sócio na Fazenda dos Macacos para abater na sobredita escritura porque Bernardo era também devedor. (...) no livro primeiro de meu compadre Ferreira deixou-me ele a dever um conto e tanto, em cobre; se eu dever-lhe igual quantia em notas só restar-me-há o câmbio que corria naquela época, e se eu não lhe dever deve-me Ferreira \& Companhia pois foram cargas que trouxe para o Tabuleiro, digo, para a Sociedade do Tabuleiro Grande. ${ }^{41}$

O testamento revela que Valentim tinha ações e investimentos em negócios diversos. É possível que a referência às açôes do Morro da Glória e à Sociedade da Lage estejam relacionadas às minas de ouro. Neste caso, a de Morro da Glória ${ }^{42}$ estava localizada em Nova Lima (MG), nas proximidades de Sabará, município ao qual havia pertencido Santa Luzia.

Ao fim do testamento, Valentim Gomes Tolentino nomeou os seus testamenteiros. Em primeiro lugar faz menção a sua esposa, em segundo ao filho Antônio e, por último, ao filho José, deixando de prêmio ao testador 400\$000. Como testemunhas, foram apresentados o tenente-coronel Francisco de Paula Lima, o capitão Francisco Rodrigues Netto, Manoel de Castro Guimarães (barão de Cataguases), Antônio José de Macedo Moura e Manoel da Silva Pontes, ${ }^{43}$ homens da elite juizdeforana que evidenciam, novamente, o prestígio de suas relaçôes pessoais. As atividades exercidas por Valentim Gomes Tolentino, sua família e seus mancípios encontram-se devidamente representadas no inventário - seja a de tropeiro, comerciante, prestamista, bem como a de lavrador e fazendeiro. Valentim possuía 44 bestas, duas bestas de esteira, uma besta de sela ordinária, um cavalo ruço velho, três poldros e 16 bois de carro mansos. Ainda relativo à atividade de tropeiro, tinha uma tenda de ferreiro com seus aparelhos, quatro quintais de ferro ${ }^{44}$ e três aparelhos de ferrar. Para dimensionarmos o tamanho de sua tropa, recorremos a José Alípio Goulart. Segundo o autor, as tropas

\footnotetext{
${ }^{41}$ AHUFJF. Inventário de Valentim Gomes Tolentino, cx. 97B, ano 1849.

${ }^{42}$ Revista do Arquivo Público Mineiro, v. 8, partes 3-4, 1903, p. 952, 998.

${ }^{43}$ Sobre Francisco de Paula Lima, ver: FREIRE, Jonis. Escravidão e família escrava na Zona da Mata Mineira oitocentista. São Paulo: Alameda, 2014. Manoel de Castro Guimarães, supomos que seja o barão de Cataguases, também morador no Piau, ver: <http://genealogiaeorigens.blogspot.com.br/2016/04/a-familiacastro-guimaraes-e-o-barao.html>. Antônio José de Macedo Moura possivelmente foi um dos vereadores da Câmara Municipal de Juiz de Fora na legislatura 1861-1864. Disponível em: <http://www.camarajf.mg.gov. br/legislaturas-passadas.php>. Para os demais não temos informações.

${ }^{44}$ Quintal é uma unidade de medida de peso equivalente a 58,752 quilos ou 4 arrobas. Nesse sentido, ver: Códice Costa Matoso. Belo Horizonte: Coleção João Pinheiro, Centro de Estudos Históricos e Culturais, 1999, p. 117, v. 2. (Coleção Mineiriana, Série Obras de Referência)
} 
eram formadas por conjuntos de lotes, sendo que cada lote tinha entre sete e nove animais. Tropas com três ou quatro lotes eram consideradas pequenas, e as tropas mineiras, em geral, eram formadas por nove cargueiros. Pela quantidade de animais que possuía, acreditamos que Tolentino era senhor de uma tropa de porte médio, com cerca de cinco ou seis lotes. ${ }^{45}$

No que tange à atividade comercial, temos evidências de que Valentim Gomes Tolentino também negociava a venda de animais de carga. No dia 21 de abril de 1849, pouco tempo depois de sua morte, Manoel Pedro Leite de Morais requereu que fosse lançada no livro do juiz de paz de Chapéu D’Uvas (distrito de Juiz de Fora) uma quitação de débito que José de Souza Barros tinha para com Valentim. De acordo com o documento, o crédito no valor de $700 \$ 000$ era relativo à compra de sete burros novos. O valor deveria ser pago em quatro pagamentos iguais e anuais, sendo que a transação havia sido realizada em fevereiro de $1843 .{ }^{46}$ O registro desse negócio nas notas do juiz de paz, logo após o falecimento de Valentim, pôde ter sido feito para evitar as cobranças pelos familiares do falecido no processo de inventário.

As dívidas ativas e passivas declaradas no testamento são um tanto quanto confusas, pois, ainda que presentes no primeiro documento, não foram arroladas nos inventários. $\mathrm{O}$ trecho do testamento, anteriormente transcrito, deixa claro que Valentim Gomes Tolentino tinha negócios em Santa Quitéria. Detinha contas de “deve e haver” com Manoel Ferreira da Silva, com quem parece ter tido uma sociedade, tendo deixado com o mesmo uma escritura em valor superior a 9:000\$000; oito açóes do Morro da Glória; e 1:000\$000 que Valentim havia dado por Ferreira na Sociedade da Lage, totalizando, assim, cerca de 12:050\$000 de haver a favor do indivíduo por nós analisado.

No cartório de Santa Quitéria havia, ainda, uma escritura de dívidas de Valentim para com o dito Ferreira, no valor de dois contos e tanto, além de 2:060\$000 e mais 600\$000 de contas que Valentim havia recebido para Ferreira (dívida de Valentim para com Ferreira). Além dessas contas bem definidas, havia outras, visto que "em poder do dito Ferreira existem cobranças minhas de diversos em Santa Quitéria, e juntamente dinheiros dados e recebidos e cujas contas ele apresentará e se levará em conta, ${ }^{47}$ além de uma quantia que havia sido emprestada em cobre, e sobre a qual se pagaria o ágio.

No inventário que foi aberto em 1849, existe uma lista com a relação de 23 devedores, de contas e dinheiros emprestados a prêmio, reforçando o argumento de que o pardo Valentim também praticava a usura. Nenhuma dessas dívidas era de grande monta, mas de qualquer modo eram significativas para o período; a maior perfazia o valor de 3:600\$000 e havia uma outra de $700 \$ 000$; todas as demais eram inferiores a $100 \$ 000$ mil réis. Havia também outra relação de 39 devedores "por acento de livro". Nesse sentido, acreditamos que essa segunda relação era de pessoas que haviam comprado mantimentos e/ou outros produtos comercializados pelo tropeiro.

\footnotetext{
${ }^{45}$ GOULART, José Alípio. Tropas e tropeiros na formação do Brasil, op. cit., p. 67-69.

${ }^{46}$ AHJF. Livros do Cartório de Chapéu D’Uvas. Livro 2, fls. 75f/v.

${ }^{47}$ AHUFJF. Inventário de Valentim Gomes Tolentino, cx. 97B, 1849.
} 
Os créditos e cobranças citados permitem afirmar que essa atividade em muito ajudou a solidificar a posição social do pardo Tolentino, ampliando também suas redes de dependência, uma vez que entre os seus credores encontramos tanto indivíduos escravos quanto pessoas livres e libertas. Os dados apresentados corroboram com as constataçôes feitas por Rita Almico, que, ao estudar o mercado de crédito em Juiz de Fora, na segunda metade do século XIX, constatou que este era bastante complexo, e "envolvia uma parcela diversificada da população em suas teias". ${ }^{48}$ Assim, ainda que Valentim tenha atuado em um contexto anterior, na primeira metade do século XIX, já se pode vislumbrar a formação de um mercado creditício. $\mathrm{O}$ ato de emprestar extrapola o fato de ser senhor e possuidor de riquezas, pressupondo também o estabelecimento de relaçóes de confiança que foram construídas ao longo dos anos.

Quando a viúva retomou o inventário, em 1855, foi informado que não havia dívidas ativas a receber e que as dívidas passivas teriam seus valores informados logo que possível, visto que os credores ainda não haviam mandado o montante correto. No documento foram citados os credores Francisco Clemente Pinto (Rio de Janeiro), Honório Augusto Ferreira Armonde (Barbacena), João de Cerqueira Dias e Francisco de Cerqueira Dias (Porto da Estrela - RJ), José Roberto Francisco dos Reis (Barbacena), Manoel Rodrigues da Costa (Borda do Campo) e a igreja de Santo Antônio do Juiz de Fora. ${ }^{49}$ Note-se, pelas localidades em que estavam situados os seus credores, a circulação e a mobilidade deste tropeiro.

Daquilo que devia, apenas nos foi informado o montante de alguns débitos. A dívida com a igreja de Santo Antônio, de $77 \$ 000$, provavelmente era relativa a recursos que estavam em poder de Valentim, uma vez que ele foi o procurador das obras da construção da nova igreja. Dos credores citados, José Roberto Francisco dos Reis informou que o crédito que tinha a receber era de 1:951\$947, o qual foi reconhecido pelos herdeiros. No inventário, consta ainda um documento de "devo que pagarei", datado de 25 de novembro de 1831, no qual Manoel Mendes Linhares (pai dos genros de Valentim) era credor, sendo o principal e os juros estimados no valor de 1:323\$000.

O processo foi encerrado sem mais informaçôes quanto aos demais débitos. Ainda assim, as dívidas ativas e passivas deixam frestas para se compreenderem as atividades tropeiras, de usura e comerciais que eram desempenhadas por Valentim Gomes Tolentino, a exemplo da dívida com Honório Ferreira Armond, membro de uma das famílias de tropeiros e de comerciantes de almas mais ricas de Minas Gerais, entre a segunda metade do século XVIII e a primeira metade do século XIX..$^{50}$

\footnotetext{
${ }^{48}$ ALMICO, Rita de Cássia da Silva. Em nome da palavra e da lei: relaçôes de crédito em Minas Gerais nos Oitocentos. Rio de Janeiro: 7 Letras, 2015, p. 43.

${ }^{49}$ AHUFJF. Inventário de Valentim Gomes Tolentino, cx. 97B, 1849.

${ }^{50}$ LACERDA, Antônio Henrique Duarte. Negócios de Minas: Família, fortuna, poder e redes de sociabilidades nas Minas Gerais — a família Ferreira Armond (1751-1850). São Paulo: Intermeios; Juiz de Fora: Funalfa, 2013.
} 
VAlentim Gomes Tolentino: A MOBILIDAde ECONÔMICA E SOCIAL VIVENCIADA por um pardo no século XIX (Zona da Mata Mineira, i 8 I 7 -I 855 )

Ana Paula Dutra Bôscaro e Elione Silva Guimarães

Quando faleceu, Valentim era proprietário de uma grande fazenda de terras de cultura, alguns cafezais, carros de milho colhidos, benfeitorias e instrumentos de trabalho, como enxadas, foices e machados. Outros objetos nos permitem inferir que a propriedade produzia farinha e cachaça, seja para subsistência ou para o comércio, uma vez que foram avaliados um forno de torrar farinha, um alambique de cachaça e tachos de tamanhos variados. Além disso, foram avaliados uma quantidade significativa de roupas, louças e móveis. Parece-nos plausível afirmar que o inventário aberto em 1849 não registrou a totalidade dos bens que o alferes Valentim Gomes Tolentino possuía naquele momento, pois o processo aberto naquele ano e o que foi aberto seis anos depois, em 1855, apresentaram diferenças significativas.

Em 1855, seis anos após a morte de Tolentino, os bens arrolados no inventário sofreram um acréscimo considerável. No ano em questão, o pardo inventariado possuía 52 mil pés de café, sendo 10 mil novos, 30 mil velhos e 12 mil pés de café no sítio, sem discriminar a idade. Além disso, foram descritas 900 arrobas de café em coco e mais 250 arrobas de café limpo, ${ }^{51}$ isto é, do produto já colhido. Havia, ainda, quatro alqueires de arroz, seis alqueires de mamona e 100 alqueires de feijăo. Valentim contava também com um grande pasto gramado, uma casa para o engenho de café, dois moinhos, um paiol, duas casas térreas, uma casa de morada e mais uma casa de sobrado..$^{52} \mathrm{~A}$ propriedade mantinha ainda 18 bestas, possivelmente utilizadas para o transporte do café da propriedade e/ou das fazendas vizinhas, e náo mais para as atividades tropeiras em longas distâncias, constituindo a chamada "tropa da casa". Foram inventariados também carneiros e suínos, sendo 31 e 58 cabeças, respectivamente.

Não sabemos ao certo por que os cafeeiros não foram descritos no primeiro inventário, se por omissão ou se pelo fato de este ter sido interrompido antes de se completar a avaliação dos bens. Certo é que foram avaliados cafezais velhos, ou seja, aqueles com mais de 25 anos, e, portanto, plantados por volta de 1830. Além disso, no inventário de 1849 já havia um crédito de café com os comissários do Rio de Janeiro. Os cafezais novos podem ser considerados como resultado da expansão das lavouras, visto que no período a produçáo de café em Santo Antônio do Juiz de Fora estava em fase ascendente..$^{53}$

A interrupção do inventário explicaria também a ausência de outros bens, como as casas e as benfeitorias, pois esses apareceram em menor proporção no primeiro documento, sendo inverossímil supor que foram adquiridos no correr deste curto intervalo de tempo. Além disso, os objetos descritos revelaram-nos certa dose de ostentação, tais como a presença de louças brancas, selas de prata, objetos em cobre, oratórios em devoção a Santa Luzia e relógios em ouro.

\footnotetext{
${ }^{51}$ Os bens arrolados foram transcritos tal como apareceram na fonte documental.

52 AHUFJF. Inventário de Valentim Gomes Tolentino, cx. 9B, 1855.

${ }^{3}$ Cf.: PIRES, Anderson. Capital agrário, investimento e crise na cafeicultura de Juiz de Fora. 1870/1930. Dissertaçáo (Mestrado) — Universidade Federal Fluminense, Niterói, 1993; OLIVEIRA, Mônica Ribeiro de. Negócios de família: mercado, terra e poder na formação da agricultura mineira - 1780-1870. Bauru, SP: Edusc; Juiz de Fora, MG: Funalfa, 2005; VITTORETTO, Bruno Novelino. O café antes do café: produçâo agrária no Vale do Parahybuna (1830-1854). Anais do XV Seminário sobre a Economia Mineira, 2012, Diamantina, MG, 2012.
} 
VAlentim Gomes Tolentino: A MOBILIDAde ECONÔMICA E SOCIAL VIVENCIADA por um pardo no século XIX (Zona da Mata Mineira, i 8 I 7 -I 855 )

Quadro 1. Inventários dos Bens de Valentim Gomes Tolentino (1849 e 1855)

\begin{tabular}{|c|c|c|c|c|}
\hline \multirow[t]{2}{*}{ Bens } & \multicolumn{2}{|c|}{ Inventário de 1849} & \multicolumn{2}{|c|}{ Inventário de 1855} \\
\hline & total & $\%$ no monte & total & $\%$ no monte \\
\hline $\begin{array}{l}\text { Cobre, prata, ferro e instru- } \\
\text { mentos de trabalho }\end{array}$ & $650 \$ 280$ & 1,19 & $361 \$ 100$ & 0,38 \\
\hline $\begin{array}{l}\text { Escravos (do monte, alforria- } \\
\text { dos, dos dotes) }\end{array}$ & $20: 190 \$ 000$ & 36,87 & $44: 680 \$ 000$ & 47,96 \\
\hline $\begin{array}{c}\text { Animais (cavalares, gado, suí- } \\
\text { nos, caprinos) }\end{array}$ & $2: 574 \$ 000$ & 4,70 & $2: 822 \$ 000$ & 3,02 \\
\hline Bens móveis & $426 \$ 000$ & 0,77 & $567 \$ 740$ & 0,60 \\
\hline Bens de raiz (terra e benfeitorias) & $21: 100 \$ 000$ & 38,53 & $25: 160 \$ 000$ & 27,01 \\
\hline Cafeeiros & & & $16: 000 \$ 000$ & 17,17 \\
\hline Mantimentos & $550 \$ 000$ & 1,00 & $1: 256 \$ 000$ & 1,34 \\
\hline Dívidas ativas & $8: 849 \$ 100$ & 16,16 & & \\
\hline Dinheiros em notas & $409 \$ 900$ & 0,74 & & \\
\hline $\begin{array}{c}\text { Café (900@ de café em coco e } \\
\text { 250@ de café limpo) }\end{array}$ & & & $2: 300 \$ 000$ & 2,46 \\
\hline Total & $54: 749 \$ 280$ & $100 \%$ & $93: 146 \$ 740$ & $100 \%$ \\
\hline
\end{tabular}

Fonte: AHUFJF. Inventário de Valentim Gomes Tolentino, cx. 97B, 1849; AHUFJF. Inventário de Valentim Gomes Tolentino, cx. 09B, 1855.

Quando faleceu, o inventariado detinha a posse de 40 escravos do monte, três quartados em testamento e 10 escravos levados à colaçáo do dote. A grande maioria de seus mancípios continuava a ser formada por homens africanos, os quais, apesar de terem idades mais elevadas, estavam ainda em pleno vigor físico. Não obstante, algumas diferenças puderam ser notadas, visto que a escravaria de Valentim contava agora com a presença de quatro idosos e 15 crianças crioulas, permitindo-nos concluir que, para além do acesso ao tráfico, os cativos passaram a se reproduzir também por via natural.

Como recomendado em testamento, Mariana havia sido libertada, e dona Joaquina declarou a morte de Manoel cabra, um cativo de aproximadamente 70 anos e de pouco valor econômico. ${ }^{54}$ Não obstante, quando comparamos os inventários de 1849 e 1855, chamou-nos a atenção a diferença dos valores com os quais os cativos foram descritos. A título de exemplo, podemos citar o caso de Romualdo Angola, que em 1849 foi avaliado em $500 \$ 000$ mil réis e em 1855 passou a valer 1:200\$000. Situação análoga foi a do escravo Paulo Crioulo, avaliado em $600 \$ 000$ réis e, seis anos depois, no valor de 1:400\$000. O preço das mulhe-

\footnotetext{
${ }^{54}$ AHUFJF. Inventário de Valentim Gomes Tolentino, cx. 9B, 1855.
} 
Valentim Gomes Tolentino: A MOBILIDAde ECONÔMICA E SOCial ViVenciada pOR uM PaRdo No SÉCulo XIX (Zona da Mata Mineira, I 8 I 7-I 855 )

Ana Paula Dutra Bôscaro e Elione Silva Guimarães

res também foi alterado, visto que em 1849 a cativa Carlota parda foi avaliada em $600 \$ 000$ mil reis e, seis anos depois, já em 1855, seu preço passou a ser de 1:800\$000.55

Durante muito tempo, o aumento do preço dos mancípios após o ano de 1850 foi atribuído quase que unicamente ao fim do tráfico transatlântico de escravos, pois os estudiosos desconsideravam uma série de fatores que também vieram a interferir nesse acréscimo. ${ }^{56}$ No entanto, pesquisas recentes têm demonstrado que, para além da abolição do comércio negreiro, da regiáo e das características físicas dos cativos, como sexo, idade, origem, doenças e ofício, o preço esteve relacionado também com a produtividade do trabalho e com o aumento da demanda dos gêneros de exportação. ${ }^{57}$ Tais argumentos permitem-nos ratificar que o preço dos mancípios que pertenciam a Valentim Gomes Tolentino (Quadro 1) não aumentou tão somente em decorrência ao fim do tráfico, mas também pela ascendente produção cafeeira que estava em vigor no município.

Como informamos, no segundo inventário as dívidas foram quitadas, e a partilha foi efetuada. O monte mor de Valentim, em 1855, foi estimado em 89:007\$140.58 O monte partilhável perfez o total de 87:104\$140. Metade deste valor coube à viúva meeira, correspondendo a 43:552\$070. A terça correspondeu a 14:517\$356. O restante foi dividido entre os cinco herdeiros já mencionados e que estavam vivos por ocasiáo da morte de Tolentino. Tendo José falecido após o pai, mas sem descendentes, sua parte foi herdada pela mãe. A legítima foi de 5:806\$942, e os legatários foram contemplados com parte dos bens de raiz, semoventes, móveis, louças, roupas e cativos. Antônio Gomes Tolentino, que foi agraciado no testamento de Valentim com uma parcela igual à dos herdeiros, vendeu sua parte ao monte, antes mesmo da execução deste segundo inventário.

Ao analisar a hierarquia de fortunas das unidades produtivas do município de Santo Antônio do Juiz de Fora, entre 1840 e 1870, Mônica Oliveira observou um padrão de desigualdades de distribuiçáo da riqueza. De acordo com as análises da autora, a composiçáo da fortuna dos grandes proprietários locais estava ligada, basicamente, a fatores agrários, como terras, cativos e cafezais. ${ }^{59}$ Decerto, a diversificação esteve presente entre as estratégias que foram utilizadas pelo alferes Tolentino, visto que, de acordo com os seus dois inventários, ele

\footnotetext{
${ }_{55}$ AHUFJF. Inventário de Valentim Gomes Tolentino, cx. 97B, 1849; AHUFJF. Inventário de Valentim Gomes Tolentino, cx. 09B, 1855.

${ }^{56}$ Cf.: MILLER, Joseph C. Slave Prices in the Portuguese Southern Atlantic, 1600-1830. In: P. E. Lovejoy (Ed.). Africans in Bondage: Studies in Slavery and the Slave Trade. Madison: University of Wisconsin Press, 1986, p. 53; BERGAD, Laird W. Slavery and the Demographic and Economic History of Minas Gerais, Brazil, 1720-1888. Cambridge: Cambridge University Press, 1999.

${ }^{57}$ VERSIANE, Flávio Rabelo; NOGUERÓL, Luiz Paulo Ferreira; VERGOLINO, José Raimundo Oliveira; RESENDE, Guilherme. Preços de escravos e produtividade do trabalho cativo: Pernambuco e Rio Grande do Sul, século XIX. In: XLI Encontro Nacional de Economia, Foz do Iguaçu. Anais do XLI Encontro de Economia, 2013, p. 16.

${ }^{58}$ A diferença entre a soma do quadro, 93:146\$470 e este monte mor é o resultado das despesas com custas, pagamentos de dívidas, escravos e animais falecidos.

59 OLIVEIRA, Mônica Ribeiro. Negócios de família: mercado, terra e poder na formação da agricultura mineira - 1780-1870, op. cit., p. 195-198.
} 
buscou investir em tropas, créditos, atividades agrícolas e também em possíveis sociedades comerciais que estavam em processo de formação na época em análise. Importa ressaltar que, na realização do inventário de 1855, foram avaliados 200 alqueires de terras de cultura, no total de 8:000\$000, na fazenda denominada São Clemente, assim como um sítio denominado Cachoeira, na fazenda do Mato Virgem, com cerca de 45 alqueires de terras, que foram vistos e avaliados no valor de 1:800\$000 réis. ${ }^{60}$

Em suma, os dados analisados demonstram que, já no ano de 1831, Valentim Gomes Tolentino muito se destacava perante a sociedade local, não somente entre os homens livres mestiços, mas também entre os proprietários brancos que ali residiam. Era detentor da maior escravaria entre os homens livres de cor que viviam em Santo Antônio de Juiz de Fora e tinha um número de cativos significativamente superior ao de outros tantos indivíduos brancos da localidade.

O fato de ser senhor de tropas e um grande proprietário de pessoas em muito favoreceu a ascensão vivenciada por ele, fazendo com que passasse a receber um tratamento mais condizente com sua situação socioeconômica. Negociar com tropas lhe possibilitou estabelecer uma ampla rede de relacionamentos entre os principais da terra, tanto na província de Minas Gerais quanto no Rio de Janeiro. Provavelmente, com o passar dos anos e o avançar da idade, ele tenha deixado de acompanhar as tropas, mas não de ser o senhor delas, fato que pôde ser comprovado pelo número de bestas que possuía quando o seu primeiro inventário foi aberto.

Estamos cientes de que a mobilidade econômica e social vivenciada por Valentim Gomes Tolentino foi possível a uma diminuta parcela da população egressa do cativeiro. Não obstante, soma-se à de outros, a exemplo dos africanos e ex-cativos Domingos Sodré, Rufino (o Alufá) e Manoel Ricardo. ${ }^{61}$ Para Juiz de Fora, nos séculos XIX e primeiras décadas do XX, podemos citar as trajetórias das famílias Balbino de Mattos e Pinto da Silva, todos pardos. Manoel Pinto da Silva, pardo livre, foi posseiro do Caminho Novo nas imediações de Juiz de Fora, e em 1818 solicitou e recebeu uma carta de sesmaria. Balbino Garcia de Mattos, arrieiro das tropas de seu senhor e provável pai, nasceu cativo, foi alforriado e constituiu uma pequena fortuna. ${ }^{62}$ Balbino Garcia de Mattos e Manoel Pinto da Silva, assim como Valentim Gomes Tolentino, legaram a seus filhos bens materiais e prestígio, o que possibilitou a alguns deles ampliar os bens recebidos e alcançar posiçôes sociais ainda mais relevantes.

\footnotetext{
${ }^{60}$ AHUFJF. Inventário de Valentim Gomes Tolentino, cx. 9B, 1855.

${ }^{61}$ REIS, João José. De escravo a rico liberto: a trajetória do africano Manoel Joaquim Ricardo na Bahia oitocentista. Revista de História, São Paulo, n. 174, p. 15-68, jan./jun., 2016; REIS, João José; GOMES, Flávio dos Santos; CARVALHO, Marcos. O alufá Rufino: tráfico, escravidão e liberdade no Atlântico negro (c. 1822c. 1853). São Paulo: Companhia das Letras, 2010; REIS, João José. Domingos Sodré, um sacerdote africano: escravidão, liberdade e candomblé na Bahia do século XIX. São Paulo, Companhia das Letras, 2008.

${ }^{62}$ Cf. GUIMARÃES, Elione. Múltiplos viveres de afrodescendentes na escravidão e no pós-emancipação: família, trabalho, terra e conflito (Juiz de Fora - MG, 1828-1928). São Paulo: Annablume; Juiz de Fora: Funalfa Edições, 2006; GUIMARÃES, Elione. A população não branca e a perspectiva de acesso e manutenção da terra, op. cit.
} 


\section{Referências bibliográficas}

\section{Fontes primárias}

Arquivo Público Mineiro (APM):

Listas Nominativas 1831-1832. CX.07-DOC.05. Disponível em: <http://www.siaapm. cultura.mg.gov.br/modules/mapas_populacao/brtacervo.php?cid=481>.

Carta de Sesmaria solicitada por Manoel da Costa Bastos. Documentos não encadernados. Cx. 19, doc. 5 .

Arquivo Nacional — Rio de Janeiro (AN-RJ):

Intendência de Polícia da Corte. Descrição no Códice 421, v. 8, 10, 16 e 21.

Ação de Força Nova. Antonio João do Valle Amado e Valentim Gomes Tolentino. 1836, Código de Referência 84.0. ACI.03632.

Arquivo Histórico Professor Altair José Savassi:

Processo Crime, 1834, cx. 78, ordem 15.

Contas Testamentárias de Manoel Mendes Linhares, 1850, cx. 3, ordem 14.

Arquivo Histórico da Universidade Federal de Juiz de Fora:

Inventário de Valentim Gomes Tolentino, cx. 97B, 1849.

Inventário de Valentim Gomes Tolentino, cx. 9B, 1855.

Ação de Força Velha de Valentim Gomes Tolentino, controle: 30A08, 1838.

Inventário de Joaquina Antônia do Nascimento, cx. 50B, 1857.

Arquivo Histórico de Juiz de Fora:

Processos Criminais do Período Imperial. Processo de Dano, 28/08/1861.

Livros do Cartório de Chapéu D’Uvas, Livro 2.

Livros do Cartório de Simão Pereira, Livro 19.

Biblioteca Nacional. Hemeroteca Digital:

Jornal $O$ Pharol, 25 de dezembro de 1889.

I0006347-2Alt=002487Lar=001708LargOri $=004541$ AltOri $=006614$.

Jornal $O$ Universal.

I0004087-9Alt=002423 Lar=001536LargOri=002048AltOri=003231. 
VAlentim Gomes Tolentino: A MOBILIDAde ECONÔMICA E SOCIAL VIVENCIADA por um pardo no século XIX (Zona da Mata Mineira, i 8 I 7 -I 855 )

\section{Pesquisa Internet:}

Instituto Brasileiro de Geografia e Estatística (IBGE). Disponível em: < https://cidades. ibge.gov.br/brasil/mg/santa-luzia/historico>. Acesso em: 15 jul. 2017.

Manoel de Castro Guimarães — o barão de Cataguases. Disponível em: <http:// genealogiaeorigens.blogspot.com.br/2016/04/a-familia-castro-guimaraes-e-o-barao.html> . Acesso em: 15 jul. 2017.

Antônio José de Macedo Moura. Disponível em: <http://www.camarajf.mg.gov.br/ legislaturas-passadas.php>. Acesso em: 15 jul. 2017.

Revista do Arquivo Público Mineiro, v. 8, partes 3-4, p. 952,998, 1903.

\section{Bibliografia}

ANASTASIA, Carla. Salteadores, bandoleiros e desbravadores nas matas gerais da Mantiqueira (1783-1786). In: PRIORE, Mary del (Org.). Revisão do paraíso. Rio de Janeiro: Campus, 2002.

ANASTASIA, Carla; LEMOS, Carmen. Vila Rica: ocupação improvisada. Oficina da Inconfidência, Ouro Preto, v. 1, n. 0, p. 26-41, dez. 1999.

ALMICO, Rita de Cássia da Silva. Em nome da palavra e da lei: relaçóes de crédito em Minas Gerais nos Oitocentos. Rio de Janeiro: 7 Letras, 2015, p. 43.

BACELLAR, Carlos de A. Prado. Viver e sobreviver em uma vila colonial: Sorocaba séculos XVIII e XIX. São Paulo: Fapesp/Annablume, 2001.

BERGAD, Laird W. Escravidão e história econômica: demografia de Minas Gerais, 17201888. Bauru: Edusc, 2004.

. Slavery and the Demographic and Economic History of Minas Gerais, Brazil, 17201888. Cambridge: Cambridge University Press, 1999.

BLASENHEIM, Peter L. As ferrovias de Minas Gerais no século XIX. Lócus: Revista de História. Juiz de Fora: Núcleo de História Regional — UFJF, EDUFJF, v. 2, n. 2, p. 81-110, 1996.

BURMEISTER, Hermann. Viagem ao Brasil através das provincias do Rio de Janeiro e Minas Gerais: visando especialmente a história natural dos distritos auri-diamantíferos. São Paulo: Martins, 1952. Códice Costa Matoso. Belo Horizonte: Coleção João Pinheiro, Centro de Estudos Históricos e Culturais, 1999, p. 117, v. 2. (Coleção Mineiriana, Série Obras de Referência)

CORDEIRO, Filipe. Os tropeiros no século XXI e o sentido contemporâneo dessa atividade: estudo de caso no Vale do Paraíba e Serra da Mantiqueira. In: X Encontro Regional Sudeste de História Oral, Campinas. Encontro Regional Sudeste de História Oral - Educação das sensibilidades: Violência, desafios contemporâneos. Campinas: Centro de Memória da Unicamp, 2013. 
COSTA, Iraci del Nero da. Arraia minida: um estudo sobre os não proprietários de escravos no Brasil. São Paulo: MGSP editores, 1992.

COTTA, Francis Albert. Os terços de homens pardos e pretos libertos: mobilidade social via postos militares nas Minas Gerais no século XVIII. Mneme, Rio Grande do Norte, v. 3, n. 6, p. 1-19, 2002.

. Fragmentos da história policial e militar de Minas Gerais: história e historiografia. Belo Horizonte: Academia de Polícia Militar de Minas Gerais, 2005.

EISENBERG, Peter L. The Sugar Industry in Pernambuco, 1840-1910; Modernization without Change. Berkeley: University of California Press, 1974.

ESCHWEGE, Wilhelm Ludwig von. Jornal do Brasil, 1811-1817 ou Relatos diversos do Brasil, coletados durante expediçôes cientificas por Wilhelm Ludwig von Eschwege. Belo Horizonte: Fundação João Pinheiro, Centro de Estudo Históricos e Culturais, 2002, p. 238. (Coleção Mineriana, Série Clássicos)

ESTEVES, Albino. Álbum do Município de Juiz de Fora. 3. ed. Juiz de Fora: Funalfa Edições, 2008. FARIA, Sheila de Castro. A Colônia em movimento: família e fortuna no cotidiano colonial. Rio de Janeiro: Nova Fronteira, 1998.

FERREIRA, Carlos Alberto Dias. Francisco Paulo de Almeida — barão de Guaraciaba: reflexôes biográficas e contexto histórico. Dissertação (Mestrado). Universo, Vassouras, 2009. Disponível em: <http://livros01.livrosgratis.com.br/cp125855.pdf>. Acesso em: 5 jun. 2017. FLORENTINO, Manolo. Em costas negras: uma história do tráfico de escravos entre África e o Rio de Janeiro. São Paulo: Companhia das Letras, 2002.

FRANCO, Maria Sylvia de Carvalho. Homens livres na ordem escravocrata. 4. ed. São Paulo: Fundação Editora da Unesp, 1997.

FRASSON, Antonio Carlos; GOMES, Silvestre Alves. Tropeirismo: processo civilizatório da região sul do Brasil, 2010. Disponível em: <http://www.educadores.diaadia.pr.gov.br/ arquivos/File/2010/artigos_teses/2010/Historia/artigos/frasson_artigo.pdf $>$. Acesso em: 11 jan. 2017.

FREIRE, Jonis. Escravidão e família escrava na Zona da Mata Mineira oitocentista. São Paulo: Alameda, 2014.

GUEDES, Roberto. Ofícios mecânicos e mobilidade social: Rio de Janeiro e São Paulo (Sécs. XVII-XIX). Topoi, Rio de Janeiro, v. 7, n. 13, p. 379-423, 2006.

. Trabalho, família, aliança e mobilidade social: estratégia de forros e seus descendentes. Vila de Porto Feliz, São Paulo, século XIX. In: Anais do V Congresso Brasileiro de História Econômica e VI Conferência Internacional de Empresas, 2003.

GOULART, José Alípio. Tropas e tropeiros na formação do Brasil. Rio de Janeiro: Conquista, 1961. GOUVÊA, Maria de Fátima. O Brasil Colonial, 1580-1720. 1. ed. Rio de Janeiro: Civilização Brasileira, 2014, v. 2. 
GUIMARÃES, Elione. A população não branca e a perspectiva de acesso e manutenção da terra. In: GOMES, Flávio; DOMINGUES, Petrônio (Orgs.). Política das raças: experiências e legados da Abolição e da pós-emancipação no Brasil. São Paulo: Selo Negro Ediçôes, 2014, p. 211-230.

Múltiplos viveres de afrodescendentes na escravidão e no pós-emancipação: família, trabalho, terra e conflito (Juiz de Fora - MG, 1828-1928). São Paulo: Annablume; Juiz de Fora: Funalfa Ediçôes, 2006.

. Tropas e tropeiros na Minas Gerais Oitocentista: Francisco Garcia de Mattos, um tropeiro na Zona da Mata Mineira. In: Anais do VI Congresso Brasileiro de História Econômica e $7^{a}$ Conferência Internacional de Empresas, Conservatória, 2005.

LACERDA, Antônio Henrique Duarte. Negócios de Minas: Família, fortuna, poder e redes de sociabilidades nas Minas Gerais — a família Ferreira Armond (1751-1850). São Paulo: Intermeios; Juiz de Fora: Funalfa, 2013.

LENHARO, Alcir. As tropas da Moderação: o abastecimento da corte na formação política do Brasil: 1808-1842. São Paulo: Ediçôes Símbolo, 1979.

LEVI, Giovanni. A herança imaterial: trajetória de um exorcista no Piemonte do século XVII. Rio de Janeiro: Civilização Brasileira, 2000.

LOPES, Eliane Cristina. O revelar do pecado: os filhos ilegítimos na São Paulo do século XVIII. São Paulo: Annablume/Fapesp, 1998.

LUNA, Francisco Vidal; KLEIN, Herbert S. Economia e sociedade escravista; Minas Gerais e São Paulo em 1830. In: LUNA, Francisco Vidal; COSTA, Iraci del Nero da; KLEIN, Herbert S. (Orgs.) Escravismo em São Paulo e Minas Gerais. São Paulo: Edusp/Imprensa Oficial do Estado de Sáo Paulo, 2009.

MILLER, Joseph C. Slave Prices in the Portuguese Southern Atlantic, 1600-1830. In: P. E. Lovejoy (Ed.). Africans in Bondage: Studies in Slavery and the Slave Trade. Madison: University of Wisconsin Press, 1986.

MONTEIRO, Nuno Gonçalo. Elites locais e mobilidade social em Portugal nos finais do Antigo Regime. Análise Social, v. 141, p. 335-368, 1997.

. Conquista do centro-sul: fundação da Colônia de Sacramento e o "achamento" das Minas. In: FRAGOSO, João Luís; GOUVÊA, Maria de Fátima. O Brasil Colonial, 15801720. 1. ed. Rio de Janeiro: Civilização Brasileira, 2014, v. 2.

OLIVEIRA, Mônica Ribeiro de. Negócios de família: mercado, terra e poder na formação da cafeicultura mineira 1780-1870. Bauru: Edusc; Juiz de Fora: Funalfa, 2005.

PIRES, Anderson. Capital agrário, investimento e crise na cafeicultura de Juiz de Fora. 1870/1930. Dissertação (Mestrado) — Universidade Federal Fluminense, Niterói, 1993.

POLLIG, João Victor Diniz Coutinho. Apropriação de terras no Caminho Novo. Dissertação (Mestrado em História) - Universidade Federal do Rio de Janeiro, Rio de Janeiro, 2012. REIS, João José. De escravo a rico liberto: a trajetória do africano Manoel Joaquim Ricardo na Bahia oitocentista. Revista de História, São Paulo, n. 174, p. 15-68, jan./jun. 2016. 
. Domingos Sodré, um sacerdote africano: escravidão, liberdade e candomblé na Bahia do século XIX. São Paulo: Companhia das Letras, 2008.

REIS, João José; GOMES, Flávio dos Santos; CARVALHO, Marcos. O alufá Rufino: tráfico, escravidão e liberdade no Atlântico negro (c. 1822-c. 1853). São Paulo: Companhia das Letras, 2010.

SALDANHA, Henrique Flávio Dias. O império da ordem: Guarda Nacional, coronéis e burocratas em Minas Gerais na segunda metade do século XIX, 1850-1873. Tese (Doutorado em História) - Universidade Estadual Paulista Júlio de Mesquita Filho, São Paulo, 2009.

SARAIVA, Luiz Fernando. O império das minas: Café e poder na Zona da Mata Mineira, 1853-1893. Tese (Doutorado) — Universidade Federal Fluminense, Niterói, 2008.

SCHWARTZ, Stuart. Escravos, roceiros e rebeldes. Bauru: Edusc, 2001, p. 286-290.

VERSIANE, Flávio Rabelo; NOGUERÓL, Luiz Paulo Ferreira; VERGOLINO, José Raimundo Oliveira; RESENDE, Guilherme. Preços de escravos e produtividade do trabalho cativo: Pernambuco e Rio Grande do Sul, século XIX. In: Anais do XLI Encontro Nacional de Economia, Foz do Iguaçu, 2013.

VITTORETTO, Bruno Novelino. O café antes do café: produção agrária no Vale do Parahybuna (1830-1854). In: Anais XV Seminário sobre a Economia Mineira, 2012, Diamantina, MG, 2012. 